\title{
Effectiveness of Rotary and Hand Files in Gutta-percha and Sealer Removal Using Chloroform or Chlorhexidine Gel
}

\author{
Carlos Eduardo da Silveira BUENO ${ }^{1,2}$ \\ Maraisa Greggio DELBONI ${ }^{2}$ \\ Roberta Aranha de ARAÚJO² \\ Hilton José CARRARA ${ }^{2}$ \\ Rodrigo Sanches CUNHA ${ }^{2}$
}

\author{
${ }^{1}$ Department of Endodontics, Pontifical Catholic University of Campinas, Campinas, SP, Brazil \\ ${ }^{2}$ Department of Endodontics, São Leopoldo Mandic Dental Research Center, Campinas, SP, Brasil
}

\begin{abstract}
The purpose of this study was to assess in vitro the efficacy of nickel-titanium $\mathrm{K}^{3}$ rotary files and hand files for removal of gutta-percha and sealer from obturated root canals using either chloroform or chlorhexidine as solvents. Sixty extracted single-rooted bovine teeth with straight, large canals were prepared, obtured and randomly assigned to 3 groups $(n=20)$. The teeth were stored at $37^{\circ} \mathrm{C}$ for 1 month and then the gutta-percha and sealer were removed using different techniques, as follows. Group I: size 3 Gates-Glidden drills plus size 30 hand K-files and Hedström files and chloroform; Group II: $\mathrm{K}^{3}$ NiTi rotary files and chloroform; and Group III: K ${ }^{3}$ NiTi rotary files and $2 \%$ chlorhexidine gel. Radiographs were taken and scanned and the images were digitized. The total area of the canal and the area with remaining obturation material were measured in millimeters using a computed image analysis system (ImageLab). Data were analyzed statistically by one-way ANOVA and Tukey test at $5 \%$ significance level. The groups differed statistically $(\mathrm{p}<0.05)$ with respect to the average percentage of remaining gutta-percha and sealer, presenting the following sequence of effectiveness (from most to least effective): Group I (15.48\%), Group II (28.42\%) and Group III (35.96\%). The findings of this study showed that, despite the technique used for removal of filling material, none of the retreated canals were completely free of gutta-percha and sealer remnants. The use of stainless steel hand files resulted in a lesser amount of filling debris than the use of nickel-titanium rotary instruments.
\end{abstract}

Key Words: endodontic retreatment, nickel-titanium $\mathrm{K}^{3}$ rotary files, solvents.

\section{INTRODUCTION}

Advances in endodontic therapy have made endodontists more interested in retreatment and surgery. The number of investigations in this area has increased considerably. An intervention is needed to correct the failure of the initial root canal treatment, disinfecting and achieving a better design. Endodontic retreatment is considered as the first choice, leaving surgery to correct a possible retreatment failure (1), caused by remaining microorganisms in the periradicular tissues (2).

Endodontic retreatment requires regaining of access to the entire root canal system through complete filling material removal. The risk of misshaping the canal by producing perforations while removing the obturation material is related to the instrument and the motion used (3). Nickel-titanium (NiTi) files have been used in root canal preparation due to their unique physical proprierties. According to the manufacturers, the use of automated endodontic files result in an appreciable gain of time as well as improvement of the operator's working conditions.

It has been reported $(4,5)$ that the retreatment time using rotary instruments was significantly shorter than that using conventional manual files. The authors concluded that the rotary movement might have produced

Correspondence: Prof. Dr. Carlos Eduardo da Silveira Bueno, Departamento de Endodontia, Centro de Pesquisas Odontológicas São Leopoldo Mandic, Rua Abolição, 1827 13045-610 Campinas, SP, Brasil. Tel: +55-19-3237-3611. Fax: +55-19-3237-3611. e-mail: carlosesbueno@terra.com.br 
a frictional heat to further soften the gutta-percha, making it easier to remove and thus requiring less solvent use. Another study (6) found that both NiTi and stainless steel hand files were effective in removing gutta-percha from the root canal system, but hand files were faster.

In clinical practice, chloroform is the most effective and widely used solvent for gutta-percha (7), especially when the root canal has a complex anatomy (5), but it can damage the local periapical tissues when extruded and its toxicity cannot be overlooked (8). Several authors (9-11) have demonstrated the biocompatibility of chlorhexidine gel with periapical tissues, as well as its broad-spectrum antimicrobial action, substantivity and low toxicity. It is therefore recommended for use as an endodontic irrigant, but it is unable to dissolve pulp tissues. Although chlorhexidine gel is not a gutta-percha solvent, its lubricant action promotes a better mechanical cleansing of the canal walls, which is necessary for rotary instrumentation technique $(9,12)$. Thus, $2 \%$ chlorhexidine gel is suggested for effective gutta-percha removal.

When retreatment is recommended, removal of obturating material, generally gutta-percha and sealer, from the root canal is a major part of the procedure. Although NiTi $\mathrm{K}^{3}$ rotary files have been used for root canal preparation, their use for removing root fillings during retreatment using chlorhexidine gel has not been reported. It is not known if the properties of chlorhexidine would aid in cleaning root canals after retreatment using rotary files. Therefore, the purpose of this study was to assess in vitro the efficacy of nickel-titanium $\mathrm{K}^{3}$ rotary files and hand files for removal of gutta-percha and sealer from obturated root canals using either chloroform or chlorhexidine gel as solvents.

\section{MATERIAL AND METHODS}

Sixty freshly extracted bovine teeth with a single straight canal and completely formed apex were selected and stored in a $10 \%$ formalin solution. The teeth were decoronated at $18 \mathrm{~mm}$ from the apex and a size $10 \mathrm{~K}$ file (Dentisply Maillefer, Ballaigues, Switzerland) was passed $1 \mathrm{~mm}$ beyond the apex of each canal to confirm patency. The same file was introduced into the canal until being visible at the apical foramen and the working length was recorded as being $1 \mathrm{~mm}$ less than that length. All canals were prepared by the same operator using a hybrid technique (13), whereby the coronal two-thirds were prepared using K-files up to size 35, followed by Gates-Glidden drills sizes 2 and 3 (Dentisply Maillefer). Apical patency was maintained by using size $10 \mathrm{~K}$-files, $1 \mathrm{~mm}$ beyond the working length, between each file and bur. Apical instrumentation started with a straight file that conformed to the apical foramen size and working length. The files were used with a half turn reaming action until the canal weakened. A size 35 file was used to establish the apical stop and to recapitulate (maintain patency). The step-back flare technique was performed with three files larger than the apical stop size.

The root canal was filled using standard guttapercha points (Tanariman, Manaus, AM, Brazil) and Endométhasone sealer (Septodont Specialités, SaintMaur, France) according to the lateral condensation technique. A heated plugged was used to remove guttapercha excesses. The cervical portion of the warm gutta-percha was vertically condensed. The access cavities were sealed with a temporary filling material (Cavit; ESPE, Seefeld, Germany) placed $1 \mathrm{~mm}$ from the coronal surface to serve as barrier to the ingress of fluids. Specimens were stored at $37^{\circ} \mathrm{C}$ for 4 weeks to simulate as closer as possible the clinical procedure. Standard obturations were obtained with use of buccolingual and proximal radiographs to examine root filling quality, apical extent and gutta-percha condensation. A single operator undertook all procedures following a predetermined protocol.

The teeth were randomly assigned to 3 groups $(n=20)$. Group I: few drops of chloroform (Merck, Darmstadt, BRD, Germany) and size 3 Gates Glidden burs were used to remove two-thirds of the root canal filling material to create a reservoir for the solvent, followed by use of size 30 stainless steel hand K-files plus size 30 Hedström files in a reaming motion to reach the working length. Group II: chloroform and $\mathrm{K}^{3}$ size 25/.10 (Sybron Dental Specialties, Orange, CA, USA) rotary files were used. The rotary files had a reduction handpiece powered by an electric motor (Endo Plus; Driller, São Paulo, SP, Brazil) with 300 rpm at a torque level of three. After two-thirds of the filling material were removed to create a reservoir for the solvent, $\mathrm{K}^{3}$ sizes 30/.06 and 30/.04 (Sybron Dental Specialties) were used to reach the working length. The operator action consisted of light apical pressure for no more than 3 to 5 seconds. Group III: the procedures were the same as in Group II, but 2\% chlorhexidine gel (Endogel; 
Endosupport, Itapetininga, SP, Brazil) was used, instead of chloroform.

Increments of chloroform and chlorhexidine $(0.1 \mathrm{~mL})$ were placed into the canal to soften the guttapercha. A total of $0.5 \mathrm{~mL}$ of both solvents was used per tooth. Softened gutta-percha was removed until the canal walls were smooth and the initial working length was reattained. The operator always followed the established criteria, making sure that no gutta-percha or sealer remnants were either visible by operating microscopy or attached to the files. There was no reinstrumentation, since the aim was only to determine the efficacy of desobturation.

Standard radiographs were taken in a buccolingual and proximal directions with $18 \mathrm{~cm}$ focus distance and an exposure time of $0.5 \mathrm{~s}$. The periapical films were processed automatically in a darkroom using an automated film processor (Dent - X 9000; AFP Imaging Corporation, Elmsford, NY, USA). The radiographs were then scanned and the images were saved in a desktop computer (Intel Pentium $200 \mathrm{MHz}, 32 \mathrm{MB}$ RAM, Manaus, AM, Brazil). One observer blinded to the methods of retreatment evaluated the root canal images. The total area as well as the area corresponding to the radiopaque filling debris were delimitated and measured in millimeters using the ImageLab 2.4 software (Softium Sistemas de Informática, São Paulo, SP, Brazil) (Fig. 1). No attempts were made to distinguish between residual gutta-percha and sealer.

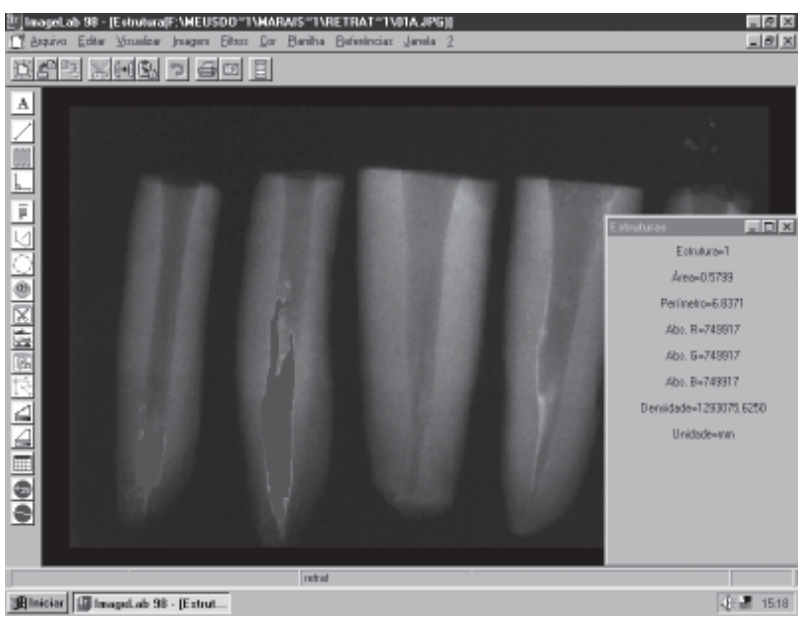

Figure 1. Measurement of the area corresponding to the radiopaque filling debris remaining after root canal retreatment techniques using ImageLab software.
Data were recorded and analyzed statistically by one-way analysis of variance and Tukey's test at 5\% significance level.

\section{RESULTS}

All teeth evaluated in this study presented filling material debris on the canal walls. Group I (hand files combined with chloroform) left $15.48 \%$ of filling material, followed by group II (rotary files and chloroform), which left $28.42 \%$ and group III (rotary files and chlorhexidine), which left $35.96 \%$. The groups differed statistically to each other $(\mathrm{p}<0.05)$.

\section{DISCUSSION}

Several retreatment techniques have been investigated trying to describe an effective, faster and easier way to remove gutta-percha and sealer from the root canal $(5,14)$, but most results have shown that manual instrumentation still plays an important role in this procedure. The findings of this study showed that none of the retreated canals were completely free of gutta-percha and sealer remnants, which is consistent with the outcomes of Wilcox et al. (15) and Sae-Lim et al. (4), who reported that it was impossible to remove all traces of gutta-percha and sealer from root canal walls with any retreatment techniques, whether used alone or combined.

The choice of using bovine teeth reflected both their availability in large number and the consideration of ethical problems. Because bovine root canal anatomy is similar to that of human teeth, they were well suited to the design of this research, which was limited to measuring the root canal area and gutta-percha/sealer area. The specimens were standardized during preparation and canals with diameter larger than size 35 files were discarded.

Testing the efficacy of a retreatment procedure requires assessing the cleanliness of root canal walls. Wilcox et al. (15) and Imura et al. (16) used a method of splitting the teeth longitudinally. In both studies, the specimens were photographed, magnified and traced. The problem of sectioning is that the filling debris can be displaced and the technique ends up being unpredictable. Images viewed from just one direction will not indicate the thickness of debris. Radiography is commonly used to evaluate cleanliness of root canals both 
clinically and experimentally and no differences have been observed when different retreatment techniques were compared (12).

According to the desobturation techniques of this study, the criteria were to use files whose tapers were smaller than the apical filling size, in such a way that they created a gap for the solvent. On the other hand, large files can cause extrusion of debris through the apex.

The tested rotary instrumentation technique did not produce entirely satisfactory results in terms of cleaning the filled root canal, even with use of chloroform or chlorhexidine. The groups in which $\mathrm{K}^{3} \mathrm{NiTi}$ rotary instruments were used showed significantly more debris, being less effective than the group desobturated with hand files. This may have occurred because the taper of the rotary instruments was not sufficient to contact all the canal walls, even with circumferential movement. On the other hand, the Hedström files were used against the walls, removing the debris on the walls in the cervical third. The design of the flutes of the Hedström files also facilitates guttapercha removal. Clearly, it would be interesting to combine rotary and hand instruments. It has been advocated (17) that the use of rotary devices in endodontic retreatment should be followed by hand instrumentation to achieve optimal cleanliness of root canal walls. Moreover, rotary instruments plasticize guttapercha through frictional heat, reaching the whole working length easily, so the rotary instruments would remove gutta-percha quickly (4), and then hand instruments could refine and complete its removal.

During retreatment, complete removal of debris is often difficult to accomplish. Effective removal of filling material should be achieved by a chemomechanical instrumentation technique that would correct canal irregularities left after the first endodontic therapy. Unlike other methodologies $(5,14)$, however, in this study, neither reinstrumentation nor complementary procedures (such as final flushing with water or any other irrigants after gutta-percha removal) were added to the protocol because all of these procedures would yield standard cleanliness of the roots and would mask solvent efficacy. No file breakage occurred during the removal of filling material.

All groups left more debris apically than coronally (18). Apically, there is increased anatomical variability and root-filling material is more difficult to remove from these areas. Because it is more likely to be infected by bacteria, the apical third should be properly shaped and cleaned. Optimal cleaning is dependent on effective canal reinstrumentation using an endodontic irrigant. In view of this, the present study also compared techniques using chlorhexidine gel, which is not a guttapercha solvent, but its lubrification was expected to improve removal of filling debris (12).

Although it has been reported that ProFile .04 taper would be a viable alternative with and without the aid of chloroform (4), another study (7) found that the solvent is essential to smooth the filling material, especially because most root canals have some degree of curvature or are oval-shaped, thus making root canal access challenging. In contrast, Ferreira et al. (5) observed that ProFile instruments or hand files used in combination with chloroform produced similarly clean canals, although Profile instruments were faster. Likewise, Sae-Lim et al. (4) showed that rotary files were faster, and the amount of residual gutta-percha and sealer was similar when compared to hand files and chloroform. Good results in gutta-percha removal have been obtained by using rotary instrumentation and chlorhexidine added to reinstrumentation (12), showing that chlorhexidine gel is indicated in endodontic retreatment. Perhaps the concept of reinstrumentation using chlorhexidine gel after gutta-percha removal using chloroform would be interesting because of the well-known properties of chlorhexidine. Further research should be done to complement the findings of this study.

\section{RESUMO}

O objetivo deste trabalho foi avaliar in vitro a eficácia de limas rotatórias $\mathrm{K}^{3}$ e limas manuais na remoção de guta-percha e cimento obturador de canais radiculares, utilizando clorofórmio ou clorexidina como solventes. Sessenta dentes bovinos extraídos unirradiculares com canais amplos e retos foram instrumentados, obturados e divididos aleatoriamente em 3 grupos $(n=20)$. Os dentes foram armazenados a $37^{\circ} \mathrm{C}$ por 1 mês e em seguida os canais foram desobturados empregando diferentes técnicas. Grupo I: brocas Gates-Glidden \#3 + limas Kerr e Hedström \#30 + clorofórmio; Grupo II: limas rotatórias $\mathrm{K}^{3}+$ clorofórmio; e Grupo III: limas rotatórias $\mathrm{K}^{3}+$ gel de clorexidina a 2\%. Após a desobturação, radiografadas dos espécimes foram feitas, escaneadas e as imagens obtidas foram digitalizadas. A área total do canal e a área com remanescente de material obturador foram medidas em milímetros por meio do software ImageLab. Os dados foram analisados estatisticamente por meio da ANOVA e do teste de Tukey. Os grupos diferiram estatisticamente $(\mathrm{p}<0,05)$ com relação à média percentual de material obturador remanescente, apresentado a seguinte ordem de efetividade (do 
mais para o menos efetivo): Grupo I (15,48\%), Grupo II (28,42\%) e Grupo III (35,96\%). Os achados deste estudo demonstraram que, a despeito da técnica empregada remoção do material obturador, os canais retratados não se mostraram completamente livres de remanescentes de guta-percha e cimento. O uso de limas de aço manuais resultou em menor quantidade de material obturador nos canais radiculares do que o uso de instrumentos rotatórios de níquel-titânio.

\section{ACKNOWLEDGEMENTS}

The authors wish to thank Rebecca Bohde for her assistance in manuscript preparation and Marcelo Correa Alves for statistical analysis.

\section{REFERENCES}

1. Allen RK, Newton CW, Brown CE. A statistical analysis of surgical and nonsurgical endodontic retreatment cases. J Endod 1989;15:261-266.

2 Lin LM, Skribner JE, Gaengler P. Factors associated with endodontic treatment failures. J Endod 1992;18:625-627.

3. Friedman S, Stabholz A, Tanse A. Endodontic retreatment Case selection and technique. Part 3: Retreatment techniques. J Endod 1990;16:543-549.

4. Sae-Lim V, Rajamanickam I, Lim BK, Lee HL. Effectiveness of ProFile.04 taper rotary instruments in endodontic retreatment. Int Endod J 2000;26:100-104.

5. Ferreira JJ, Rhode JS, Pitt Ford TR. The efficacy of guttapercha removal using ProFiles Int Endod J 2001;34:267-274.

6. Barrieshi-Nusair KM. Gutta-percha retreatment: effectiveness of nickel-titanium rotary instruments versus stainless steel hand files, J Endod 2002;28:454-456.

7. Oyama KO, Siqueira EL, Santos M. In vitro study of effect of solvent on root canal retreatment. Braz Dent J 2002;13:208211.
8. Barbosa SV, Burkard DH, Spängberg LSW. Cytotoxic effects of gutta-percha solvents. J Endod 1994;20:6-8.

9. Ferraz CCR, Gomes BPFA, Zaia AA, Teixeira FB, SouzaFilho FJ. In vitro assessment of the antimicrobial action and the mechanical ability of chlorhexidine gel as an endodontic irrigant. J Endod 2001;27:452-455.

10. Jeansonne MJ, White RR. A comparison of $2.0 \%$ chlorhexidine gluconate and $5.25 \%$ sodium hypochlorite as antimicrobial endodontic irrigants. J Endod 1994,20:276278.

11. White RR, Hays GL, Janer LR. Residual antimicrobial activity after canal irrigation with chlorhexidine. J Endod 1997;23:229-231.

12. Bharathi G, Chacko $\mathrm{Y}$, Lakshminarayanan L. An in vitro analysis of gutta-percha removal using three different techniques. Endodontol 2002;14:41-45.

13. Berber VB, Gomes BPFA, Sena NT, Vianna CCR, Ferraz CCR, Zaia AA, Souza-Filho FJ. Efficacy of various concentrations of $\mathrm{NaOCl}$ and instrumentation techniques in reducing Enterococcus faecalis within root canals and dentinal tubules. Int Endod J 2006;39:10-17.

14. Betti LV, Bramante CM. Quantec SC rotary instruments versus hand files for gutta-percha removal in root canal retreatment. Int Endod J 2001;34:514-519.

15. Wilcox LR, Krell KV, Madison S, Rittman B. Endodontic retreatment: evaluation of gutta-percha and sealer removal and canal reinstrumentation. J Endod 1987;13,453-457.

16. Imura N, Kato AS, Hata G-I, Uemura M, Toda T, Weine F. A comparison of the relative efficacies of four hand and rotary instrumentation techniques during endodontic retreatment. Int Endod J 2000;33:361-366.

17. Hulsmann M, Stotz S. Efficiency, cleaning ability and safety of different devices for gutta-percha in root canal retreatment. Int Endod J 1997;30:227-233.

18. Masiero AV, Barletta FB. Effectiveness of different techniques for removing gutta-percha during retreatment. Int Endod J 2005;38:2-7. 